\title{
Climate change and the spring bloom: a mesocosm study on the influence of light and temperature on phytoplankton and mesozooplankton
}

\author{
Aleksandra Lewandowska*, Ulrich Sommer \\ Leibniz-Institute for Marine Sciences IFM-GEOMAR, Düsternbrooker Weg 20, 24105 Kiel, Germany
}

\begin{abstract}
We examined the simultaneous effect of climate warming and light availability on the phytoplankton spring bloom using $1400 \mathrm{l}$ (1 $\mathrm{m}$ depth) indoor mesocosms. The timing of the spring bloom was advanced both by warming and higher light intensity, but the influence of temperature on the phytoplankton community was stronger than the light effect. Warming affected phytoplankton directly and indirectly via enhanced grazing pressure at higher temperatures. Warming resulted in markedly lower phytoplankton biomass and a shift towards smaller cell sizes. It also led to changes in the community structure of phytoplankton and zooplankton. Among phytoplankton, large-celled diatoms were most negatively affected by warming. Overwintering zooplankton species (Oithona, Pseudocalanus) remained dominant in the cold treatments, while they were replaced by late spring or summer species (Acartia, Centropages, Temora) in the warmed treatments. Our results show that understanding food web interactions might be very important to the study of the effects of climate warming on pelagic ecosystems.
\end{abstract}

KEY WORDS: Climate change $\cdot$ Phytoplankton $\cdot$ Spring bloom $\cdot$ Mesocosm experiment $\cdot$ Food web

\section{INTRODUCTION}

Global warming is considered to be one of the most important chronic factors driving future ecosystem changes. Aquatic ecosystems have a climate-buffering capacity due to their impact on the global carbon cycle (biological $\mathrm{CO}_{2}$-pump), and each disturbance may irretrievably change the functioning of the Earth ecosystem (Schiermeier 2006).

The temperature of ocean surface waters is predicted to increase by 1 to $6^{\circ} \mathrm{C}$ within the 21 st century, depending on the climate scenario (IPCC 2007). As a consequence of this warming, the structure of marine ecosystems is expected to change. Drastic changes in phytoplankton community structure provoke a chain reaction in marine food webs and might result in the removal of top predators or herbivores (Smetacek \& Cloern 2008). However, marine ecosystems are also controlled by top-down processes. Warming might affect the abundance of top predators and herbivores and change grazing pressure. Strong top-down effects of marine fishes on zooplankton with warming have been shown by Mueter et al. (2009), but the relative strength of bottom-up and top-down control in the marine environment across all trophic levels needs to be better understood.

The spring phytoplankton bloom is one of the most important seasonal patterns in pelagic food webs, supplying energy to the higher trophic levels after winter (Townsend et al. 1994). Suspected shifts in the timing of spring blooms (Edwards \& Richardson 2004) may cause a mismatch between food supply by phytoplankton and food demand by zooplankton according to the match-mismatch hypothesis (Cushing 1990), thereby disturbing the energy flow through the system.

In deep, well-stratified water bodies, seasonal warming and the seasonal onset of higher light availability are coupled triggers of the spring bloom, because thermal stratification increases the mean light exposure of phytoplankton cells circulating in the mixed water 
layer (Sverdrup 1953). In shallower, well-mixed water bodies or in systems where non-seasonal haloclines restrict mixing even in winter, the spring bloom can start before the onset of thermal stratification (Reynolds 2006, Sommer et al. 2007, Sommer \& Lengfellner 2008). Under such conditions, seasonal phytoplankton growth can start at extremely low temperatures because light-limited photosynthesis is rather insensitive to temperature (Tilzer et al. 1986). However, trophic interactions should be strongly modified, because heterotrophic processes tend to be more sensitive to temperature (Rose et al. 2009). Thus, we can suspect that warming without increasing light availability will lead to higher grazing rates by overwintering zooplankton that will not be balanced by a concomitant increase of primary productivity. An earlier onset of grazing might reduce the size of the phytoplankton community before light conditions permit the built-up of the phytoplankton spring bloom, thus leading to food shortage for zooplankton (Durant et al. 2005), particularly for the starvation-sensitive larval stages.

Although numerous experiments on the response of natural phytoplankton communities to light intensity or temperature changes have been published (Keller et al. 1999, Huisman et al. 2004, Elliott et al. 2006), there are few studies where both factors are addressed with experiments (Berger et al. 2007, Sommer \& Lengfellner 2008). Several field observations have shown that increasing temperature provoked changes in community structure and dynamics of the phytoplankton bloom (Winder \& Schindler 2004, Thackeray et al. 2008, Nixon et al. 2009). A strong impact of light on the phytoplankton spring bloom was observed by Berger et al. (2007) in their in situ enclosure experiments of a freshwater ecosystem. They did not observe any temperature effect on phytoplankton biomass or bloom timing, although the abundance of mesozooplankton changed with warming. Our previous experiments (Sommer \& Lengfellner 2008) with an indoor mesocosm system with the natural plankton community from the Baltic Sea (mesozooplankton added from net catches at the same concentration as the present study, see 'Materials and methods') suggested a weak temperature effect on the timing of the phytoplankton spring bloom, but a strong temperature effect on phytoplankton biomass and composition. Three experiments performed in different years under different light regimes preliminarily suggested a strong light effect on timing, phytoplankton biomass and composition (Sommer \& Lengfellner 2008); however, these studies were not a factorial combination of light and temperature within the same experiment and therefore not a rigorous test of the relative importance of light and temperature effects. Therefore, in the present study we utilized an experimental design of 2 temper- ature scenarios $\left(\Delta \mathrm{T}=0\right.$ and $\left.6^{\circ} \mathrm{C}\right)$ and 3 light regimes $(32,48$ and $64 \%$ of sea surface irradiance) in a factorial combination to test the relative importance of climate warming and light availability on the phytoplankton spring bloom.

\section{MATERIALS AND METHODS}

Experimental design. Twelve mesocosms were deployed in 4 climate chambers where temperature could be programmed. Light could be regulated individually for each mesocosm. We tested 2 temperature and 3 light scenarios, resulting in 6 treatment combinations; each treatment was duplicated. Each mesocosm was $1400 \mathrm{l}$ in volume and $1 \mathrm{~m}$ deep, with a gently moving propeller that mixed the water column. Mesocosms were filled with the natural winter plankton community containing algae, bacteria and protozoa from Kiel Bight, Baltic Sea. Mesozooplankton dominated by Oithona sp. was added from net catches at a natural concentration of ca. 10 ind. $\mathrm{l}^{-1}$ (Behrends 1996). Initial nutrient concentrations were $13.8 \mu \mathrm{mol} \mathrm{l}^{-1}$ nitrate, $0.9 \mu \mathrm{moll}^{-1}$ phosphate, $30.0 \mathrm{\mu mol} \mathrm{l}^{-1}$ silicate and $0.9 \mu \mathrm{mol}^{-1}$ ammonium. Such concentrations were high enough to preclude nutrient limitation until the biomass peak was reached.

The temperature program was derived from the decadal mean (1993 to 2002) of water surface temperatures in Kiel Bight. We used 2 temperature regimes (Fig. 1): (1) baseline (i.e. $0^{\circ} \mathrm{C}$ elevation above the decadal mean, $\left.\Delta \mathrm{T}=0^{\circ} \mathrm{C}\right)$ and $(2)+6^{\circ} \mathrm{C}$ above the baseline $\left(\Delta \mathrm{T}=6^{\circ} \mathrm{C}\right)$, in agreement with the most drastic climate scenario presented by IPCC (2007).

Light conditions mimicked daily irradiance curves and seasonal light patterns according to the astronomic model by Brock (1981). We reduced the natural irradi-

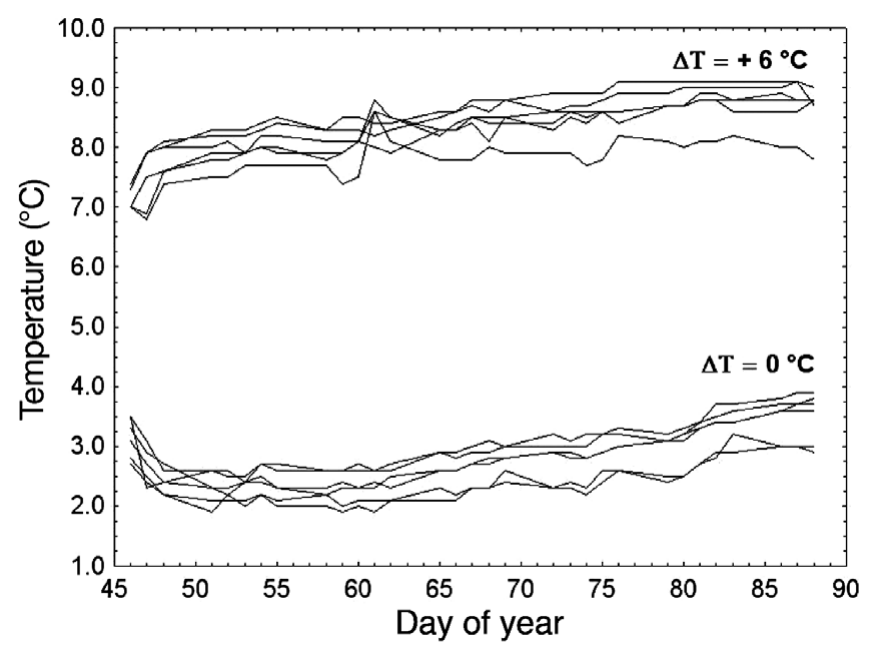

Fig. 1. Temperature profiles for all 12 mesocosms. $\Delta \mathrm{T}$ : elevation of temperature 
ance to 32,48 and $64 \%$ of sea surface irradiance $\left(\mathrm{I}_{0}\right)$ on cloudless days to test 3 light scenarios. The highest $\mathrm{I}_{0}$ (64\%) was based on a mixed water column mean light intensity during cloudless days at $10 \mathrm{~m}$ mixing depth (depth of the halocline in situ) and a vertical attenuation coefficient $(k)$ of $0.18 \mathrm{~m}^{-1}$. The $32 \% \mathrm{I}_{0}$ corresponded to $50 \%$ light reduction by cloud cover or any combination of less clouds and a higher attenuation coefficient.

The light system was controlled by a computer program (GHL, Prometeus). The starting date for the light and the temperature programs was set at 15 February (day of year [DOY] 46).

Sampling and plankton estimation. Water temperature, fluorescence, $\mathrm{pH}$ and nutrient concentrations were measured every day to monitor the system. Samples for phytoplankton counts were taken 3 times per week from the mid depth of mesocosms and fixed with Lugol's iodine. Samples for flow cytometry and primary production measurements were taken at the same time and measured immediately. Mesozooplankton samples were taken weekly using a net $(12 \mathrm{~cm}$ in diameter, $64 \mu \mathrm{m}$ mesh size), fixed with Lugol's iodine and counted with a binocular microscope (Leica MS5).

Phytoplankton were counted using the inverted microscope method (Utermöhl 1958). For cells smaller than $5 \mu \mathrm{m}$, flow cytometry (FACScalibur, Becton Dickinson) was used. Flow cytometric phytoplankton categories were distinguished by size and pigment fluorescence (chlorophyll $a$ and phycoerythrin). Cell volumes were calculated after approximation to geometric models (Hillebrand et al. 1999) and converted into carbon content as described by Menden-Deuer \& Lessard (2000).

In order to provide a simplified image of phytoplankton composition, phytoplankton species were aggregated into functional groups (see Table 3): microdiatoms, nanodiatoms, bentho-pelagic diatoms, nanoflagellates, dinoflagellates and picoplankton. Microdiatoms were classified as species $>20 \mu \mathrm{m}$, nanodiatoms were classified as species $<20 \mu \mathrm{m}$ and bentho-pelagic diatoms were distinguished separately. Nanoflagellates did not include dinoflagellates, which were grouped separately. Species $<2 \mu \mathrm{m}$ were classified as picoplankton.

Measurements of primary production. Primary production was measured by the ${ }^{14} \mathrm{C}$ incorporation method after Gargas (1975). ${ }^{14} \mathrm{C}$-bicarbonate with $4 \mu \mathrm{Ci}$ per $30 \mathrm{ml}$ sample was used. Duplicate samples, as well as a blank (dark) sample, were incubated during 3 to $4 \mathrm{~h}$ inside the mesocosms at mid depth. Following incubation, samples were filtered through cellulosenitrate membrane filters $(0.2 \mu \mathrm{m}$ pore size). Filters were fumed with $\mathrm{HCl}$ and fixed with Lumagel scintillation cocktail. Radioactivity was measured by a liquid scintillation counter (Tricarb counter, Packard).

Statistical analyses. To test light and temperature effects, we used general regression models (best sub- sets, $\mathrm{R}^{2}$ ) using STATISTICA 6 with temperature as the categorical factor and light as the continuous factor. If not stated otherwise, statistics were based on maximal phytoplankton biomass to exclude the effect of pseudoreplication by interdependent measurements over time.

Timing of the phytoplankton bloom was defined by cardinal points: beginning of the bloom (BB), the day when the community biomass was at a maximum (MB) and end of the bloom (EB). Species-specific biomass was transformed according to standard normal variation. BB and EB were the days corresponding to the first and third quartiles, respectively, of the maximal biomass.

We compared the taxonomic phytoplankton composition in the mesocosms by conducting analysis of similarities (ANOSIM) and multidimensional scaling (MDS) using PRIMER 5, based on the Bray-Curtis dissimilarity coefficient.

\section{RESULTS}

\section{Time of the bloom}

The phytoplankton bloom started about 1 wk earlier under warmer conditions (Table 1). We found a significant effect of warming on BB ( $p<0.001, r=0.92), M B$ $(p<0.001, r=0.79)$ and EB $(p<0.05, r=0.81)$. The MB at the lower temperature level $\left(\Delta \mathrm{T}=0^{\circ} \mathrm{C}\right)$ was achieved at DOY 65 for 48 and $32 \%$ of $\mathrm{I}_{0}$ and at DOY 62 for the highest light intensity $\left(64 \%\right.$ of $\left.\mathrm{I}_{0}\right)$. In the warmer treatments $\left(\Delta \mathrm{T}=6^{\circ} \mathrm{C}\right), \mathrm{MB}$ was achieved at DOY 58, 60 and 62 depending on the light conditions $(\mathrm{p}<0.001, \mathrm{r}=$ 0.79 for interaction between temperature and light

Table 1. Date of the spring phytoplankton bloom (day of year). $\Delta \mathrm{T}$ : elevation of temperature; $\mathrm{I}_{0}$ : percentage of sea surface irradiance tested; BB: beginning of the bloom; MB: day of maximal biomass; EB: end of the bloom

\begin{tabular}{|ccccc|}
\hline$\Delta \mathrm{T}\left({ }^{\circ} \mathrm{C}\right)$ & $\mathrm{I}_{0}(\%)$ & $\mathrm{BB}$ & $\mathrm{MB}$ & $\mathrm{EB}$ \\
\hline 0 & 32 & 58 & 65 & 83 \\
& & 58 & 65 & 83 \\
& 48 & 53 & 65 & 81 \\
& & 55 & 65 & 83 \\
& 64 & 58 & 62 & 86 \\
& & 55 & 62 & 81 \\
6 & & 51 & 62 & 79 \\
& & 48 & 62 & 79 \\
& & 48 & 60 & 76 \\
& 48 & 48 & 60 & 69 \\
& & 48 & 58 & 74 \\
& & 48 & 58 & 76 \\
\hline
\end{tabular}


intensity, see also Table 1). The bloom duration was similar among all treatments and did not depend on temperature or light ( $p>0.05$, average duration time: $27 \pm 2 \mathrm{~d}[\mathrm{SD}])$.

\section{Phytoplankton growth and cell size}

Growth dynamics of the phytoplankton in our experiment were typical for the spring bloom with an exponential increase, a short peak and decline of biomass until the clear water phase was achieved (Fig. 2, see also Reynolds 2006). Small species like picoplankton and nanoflagellates predominated at the beginning and the end of the experiment. During the bloom period there was a shift towards dominance by diatoms with smaller species at the beginning and a subsequent succession towards larger ones.

Primary production started to increase earlier in warmer conditions, but it did not achieve higher maximal values in warmer mesocosms than in the colder ones (Fig. 3). There was no significant difference in maximal primary production between the 2 temperature conditions ( $\mathrm{p}>0.05)$. However, the primary production/
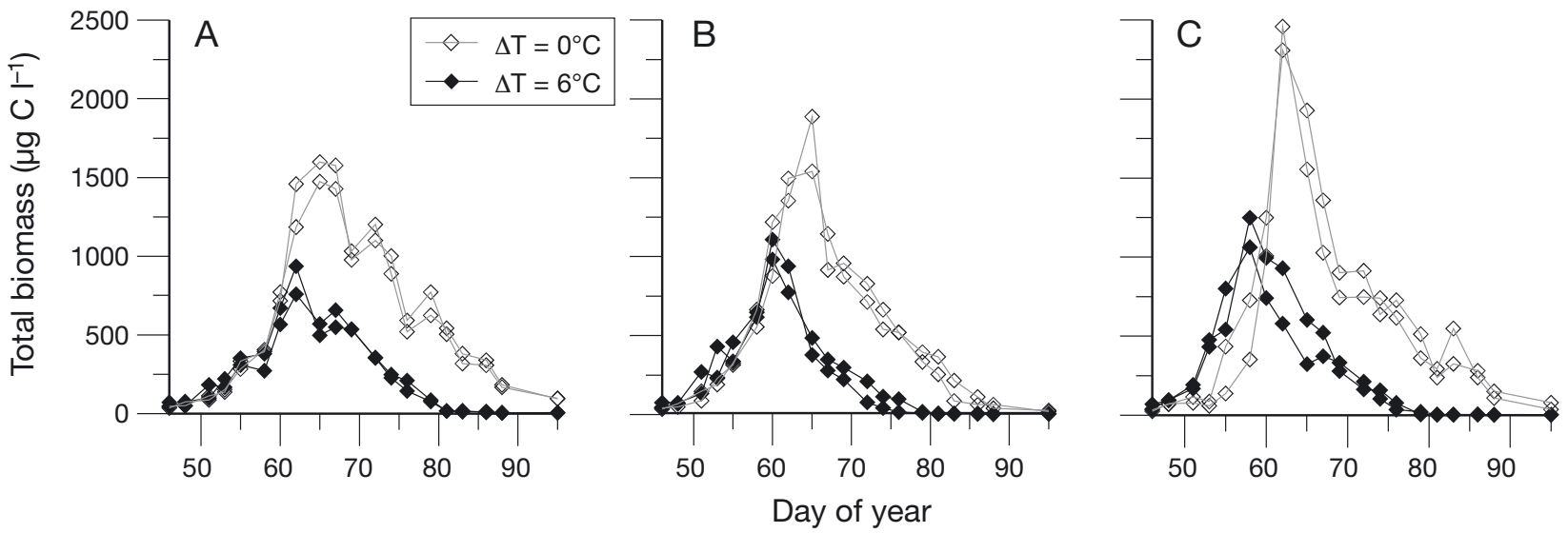

Fig. 2. Total biomass of phytoplankton under the different light and temperature conditions. (A) $32 \%$ of sea surface irradiance $\left(\mathrm{I}_{0}\right)$; (B) $48 \%$ of $\mathrm{I}_{0 ;}$ (C) $64 \%$ of $\mathrm{I}_{0}$. Open and filled symbols correspond to different temperature regimes $\left(\Delta \mathrm{T}=0\right.$ or $6^{\circ} \mathrm{C}$, respectively)
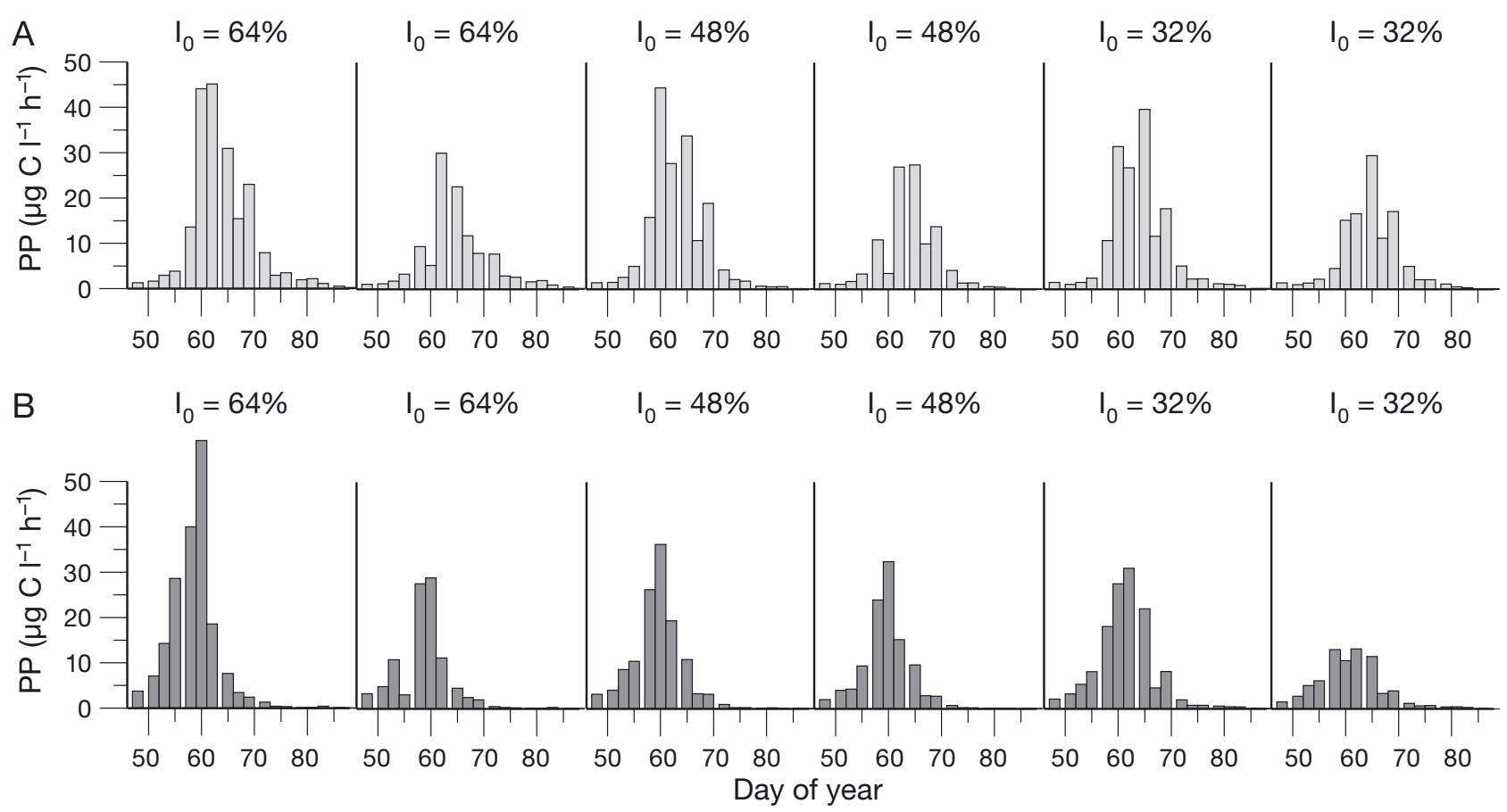

Fig. 3. Primary production (PP) under (A) control conditions and (B) elevated temperature with different light scenarios (32, 48 and $64 \%$ of sea surface irradiance) in the 12 mesocosms 
biomass ratio (P/B) was slightly higher under warmer conditions relative to colder conditions (warmer: $\mathrm{P} / \mathrm{B}=$ $0.28 \mathrm{~d}^{-1} \pm 0.09$ [SD]; colder: $\mathrm{P} / \mathrm{B}=0.19 \mathrm{~d}^{-1} \pm 0.05$ [SD]; $\mathrm{p}=0.048)$. We found that light had a positive, though insignificant ( $p>0.05)$, effect on primary production during the bloom in the warmer mesocosms. After the bloom, primary production decreased rapidly in the warmer mesocosms, whereas a more gradual decline in the colder mesocosms was observed (Fig. 3). These changes in primary production corresponded to changes in microdiatom biomass (Fig. 4).

At elevated temperatures $\left(\Delta \mathrm{T}=6^{\circ} \mathrm{C}\right)$, lower total biomass $(\mathrm{p}<0.001, \mathrm{r}=-0.83$ ) and higher picophytoplankton biomass $(\mathrm{p}<0.001, \quad \mathrm{r}=0.25) \quad$ were observed (Fig. 2), suggesting a shift to smaller cell sizes with warming. Indeed, the mean cell size was smaller under warmer conditions ( $p=0.01, r=0.69$; Table 2$)$.

\section{Phytoplankton community structure}

Twenty phytoplankton species were counted using inverted microscopy and flow cytometry. Additionally, the smallest fraction (picoplankton, $<2 \mu \mathrm{m}$ ) was distinguished without species identification. Picophytoplankton were present in all treatments, but varied in abundance between colder and warmer mesocosms (Table 3). Phytoplankton biomass was dominated by diatoms. Diatoms differed in size (microdiatoms,

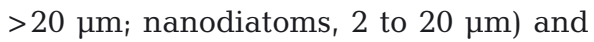
function (planktonic and bentho-pelagic diatoms, the latter were an indicator of algal growth on mesocosm walls).

The diatom Skeletonema costatum was the most abundant species under all conditions (Table 3). It played a major role in forming the bloom, achieving $55 \pm 8 \%$ of maximal total biomass in the warmer mesocosms and $19 \pm 5 \%$ of maximal total biomass in the colder mesocosms. In the cold mesocosms, Thalassiosira rotula and Chaetoceros curvisetus were also highly abundant species, as opposed to in the warmer mesocosms (Table 3). We counted 30 times more $T$. rotula and 10 times more C. curvisetus in colder mesocosms than in warmer mesocosms. In the colder treatments $\left(\Delta \mathrm{T}=0^{\circ} \mathrm{C}\right), T$. rotula $(39 \pm$
$6 \%$ of maximal total biomass) formed the bloom together with $S$. costatum and Rhizosolenia setigera, whereas under warmer conditions $\left(\Delta \mathrm{T}=6^{\circ} \mathrm{C}\right) \mathrm{T}$. rotula played only marginal role in forming the bloom $(3 \pm$ $1 \%$ of maximal total biomass).

Bloom-forming species (Skeletonema costatum, Rhizosolenia setigera, Thalassiosira rotula) showed highly significant $(R$. setigera and $T$. rotula, $\mathrm{p}<0.001 ;$ S. costa-

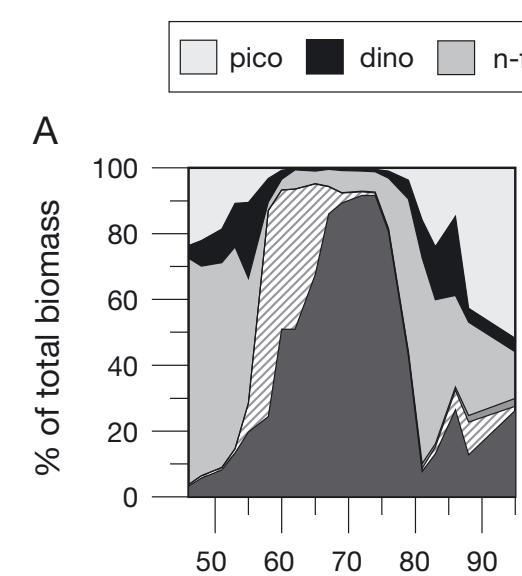

B

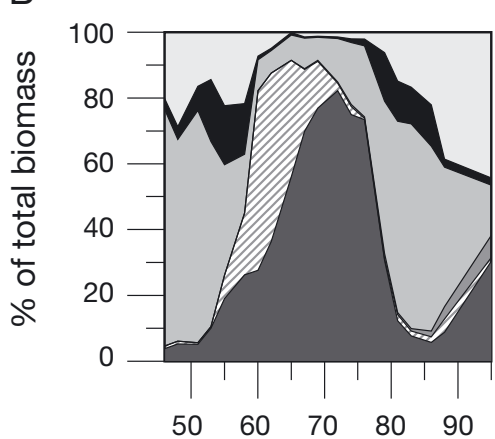

C

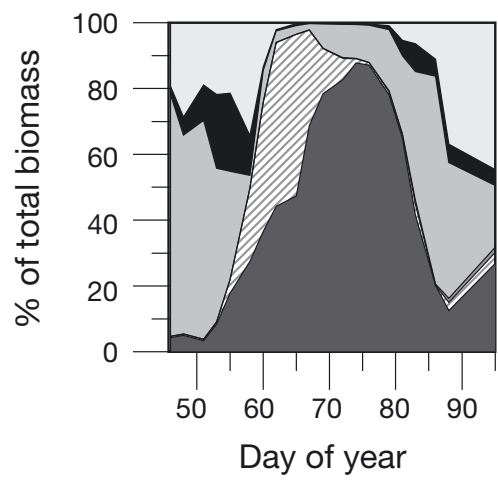

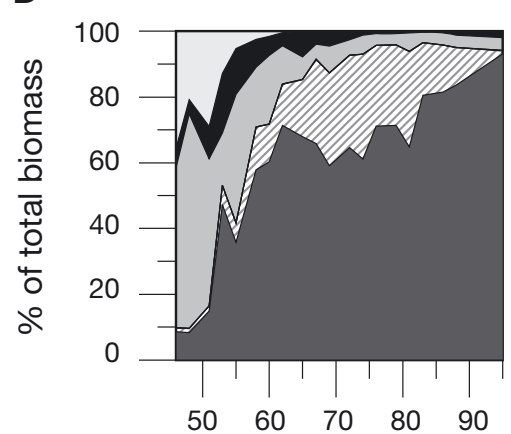

$E$

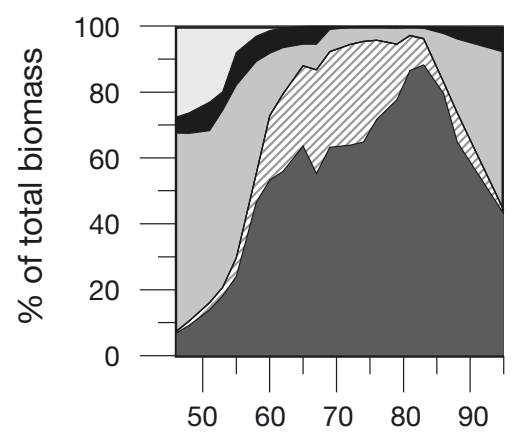

F

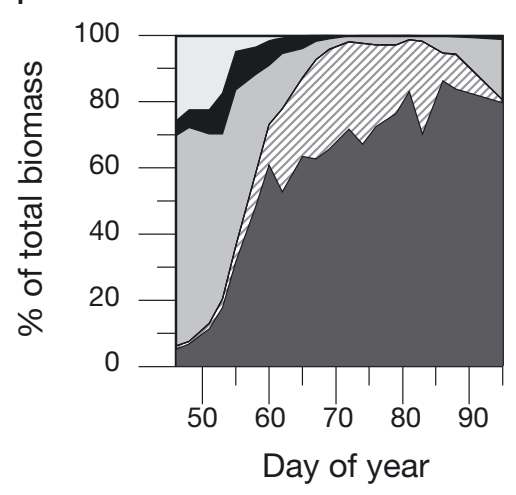

Fig. 4. Relative phytoplankton biomass ( $\%$ of total) for the different functional groups (mean of 2 replicates). (A) $\Delta \mathrm{T}=6^{\circ} \mathrm{C}$ and $64 \%$ of $\mathrm{I}_{0 ;}$ (B) $\Delta \mathrm{T}=6^{\circ} \mathrm{C}$ and $48 \%$ of $\mathrm{I}_{0 i}(\mathrm{C}) \Delta \mathrm{T}=6^{\circ} \mathrm{C}$ and $32 \%$ of $\mathrm{I}_{0 ;}(\mathrm{D}) \Delta \mathrm{T}=0^{\circ} \mathrm{C}$ and $64 \%$ of $\mathrm{I}_{0 i}(\mathrm{E}) \Delta \mathrm{T}=0^{\circ} \mathrm{C}$ and $48 \%$ of $\mathrm{I}_{0} ;(\mathrm{F}) \Delta \mathrm{T}=0^{\circ} \mathrm{C}$ and $32 \%$ of $\mathrm{I}_{0}$. m-diat: microdiatoms; n-diat: nanodiatoms; b-diat: benthic diatoms; $\mathrm{n}$-flag: nanoflagellates; dino: dinoflagellates; pico: picoplankton 
Table 2. Mean cell size (pg C cell ${ }^{-1}$ ) of phytoplankton under the different light and temperature conditions. $\Delta \mathrm{T}$ : elevation of temperature; $\mathrm{I}_{0}$ : percentage of sea surface irradiance tested. Values represent the mean size of phytoplankton cells for each mesocosm during the bloom time period

\begin{tabular}{|lccc|}
\hline \multirow{2}{*}{$\Delta \mathrm{T}$} & \multicolumn{3}{c|}{ Mean cell size } \\
\cline { 2 - 4 } & $\mathrm{I}_{0}=32 \%$ & $\mathrm{I}_{0}=48 \%$ & $\mathrm{I}_{0}=64 \%$ \\
\hline $0^{\circ} \mathrm{C}$ & 35 & 34 & 38 \\
& 41 & 46 & 38 \\
$6^{\circ} \mathrm{C}$ & 21 & 7 & 27 \\
& 25 & 23 & 41 \\
\hline
\end{tabular}

tum, $\mathrm{p}<0.01$ ) responses to warming (Table 4). The biomass of other diatoms also varied significantly between the 2 temperature levels, except for the pennate diatoms Pseudo-nitzschia sp., Thalassionema nitzschioides and the rare bentho-pelagic diatom Nitzschia acicularis, which did not show any effect. The most important (in terms of biomass) and most abundant dinoflagellates, Gymnodinium ostenfeldi and Hetero- capsa rotundata, showed a significant response to warming as well as to changes in the light regime (Table 4). Coscinodiscus sp. showed a similar pattern, but it was a rare species. Dinobryon balticum, Tetraselmis sp. and Gyrodinium fusiforme were absent during the bloom time period and they were excluded from Table 4 .

We calculated the percentage of total biomass for each functional group across the bloom period and found clear responses to warming (Table 3, Fig. 4). After the bloom, the proportion of diatoms declined rapidly in warmer conditions, whereas in colder tanks, this decrease was much slower (Fig. 4).

\section{Light versus temperature effects}

The effect of light and temperature on the taxonomic composition of phytoplankton biomass was analyzed by calculating the dissimilarity (Bray-Curtis dissimilarity coefficient) between the different mesocosms and using a subsequent MDS plot. The MDS plot showed a clear

Table 3. Functional groups of phytoplankton. m-diat: microdiatoms; n-diat: nanodiatoms; b-diat: benthic diatoms; n-flag: nanoflagellates; dino: dinoflagellates; pico: picoplankton. Rare species (only single cells) are marked with + and - for presence and absence, respectively

\begin{tabular}{|c|c|c|c|c|}
\hline \multirow[t]{2}{*}{ Phytoplankton group } & \multicolumn{2}{|c|}{ Mean maximal abundance $\left(\right.$ cell ml $\left.{ }^{-1} \pm \mathrm{SD}\right)$} & \multicolumn{2}{|c|}{ Percent of maximal total biomass $( \pm \mathrm{SD})$} \\
\hline & $\Delta \mathrm{T}=0^{\circ} \mathrm{C}$ & $\Delta \mathrm{T}=6^{\circ} \mathrm{C}$ & $\Delta \mathrm{T}=0^{\circ} \mathrm{C}$ & $\Delta \mathrm{T}=6^{\circ} \mathrm{C}$ \\
\hline \multicolumn{5}{|l|}{ m-diat } \\
\hline Ceratulina pelagica & $6 \pm 4$ & + & + & - \\
\hline Chaetoceros curvisetus & $478 \pm 199$ & $60 \pm 50$ & $2 \pm 1$ & + \\
\hline Coscinodiscus sp. & + & + & + & + \\
\hline Proboscia alata & $57 \pm 13$ & $34 \pm 10$ & + & $1 \pm 1$ \\
\hline Pseudo-nitzschia sp. & $2420 \pm 733$ & $3373 \pm 1309$ & $1 \pm 0$ & $2 \pm 2$ \\
\hline Rhizosolenia setigera & $3 \pm 1$ & $6 \pm 5$ & $21 \pm 2$ & $20 \pm 8$ \\
\hline Thalassionema nitzschioides & $225 \pm 69$ & $330 \pm 34$ & $1 \pm 1$ & $3 \pm 2$ \\
\hline Thalassiosira nordenskioeldi & $74 \pm 15$ & $145 \pm 74$ & $1 \pm 0$ & $3 \pm 2$ \\
\hline Thalassiosira rotula & $464 \pm 170$ & $17 \pm 8$ & $39 \pm 6$ & $3 \pm 1$ \\
\hline \multicolumn{5}{|l|}{ n-diat } \\
\hline Chaetoceros minimum & $4454 \pm 1278$ & $2889 \pm 1107$ & $2 \pm 1$ & $1 \pm 1$ \\
\hline Skeletonema costatum $^{\mathrm{a}}$ & $32366 \pm 4418$ & $46877 \pm 11911$ & $19 \pm 5$ & $55 \pm 8$ \\
\hline \multicolumn{5}{|l|}{ b-diat } \\
\hline Nitzschia acicularis & $65 \pm 48$ & $77 \pm 33$ & + & + \\
\hline \multicolumn{5}{|l|}{ n-flag } \\
\hline Dinobryon balticum & $904 \pm 199$ & $84 \pm 28$ & - & - \\
\hline Rhodomonas sp. & $244 \pm 218$ & $79 \pm 41$ & $3 \pm 3$ & $1 \pm 1$ \\
\hline Teleaulax amphioxeia & $531 \pm 111$ & $592 \pm 151$ & $6 \pm 4$ & $4 \pm 4$ \\
\hline Tetraselmis sp. & $3 \pm 3$ & $21 \pm 14$ & - & - \\
\hline \multicolumn{5}{|l|}{ dino } \\
\hline Ceratium tripos & + & + & - & + \\
\hline Gymnodinium ostenfeldi & $21 \pm 13$ & $9 \pm 2$ & + & + \\
\hline Gyrodinium fusiforme & + & + & - & - \\
\hline Heterocapsa rotundata & $1662 \pm 523$ & $1837 \pm 732$ & $4 \pm 2$ & $3 \pm 3$ \\
\hline \multicolumn{5}{|l|}{ pico } \\
\hline $\begin{array}{l}\text { Picoplankton from flow cytometry } \\
\text { counting (not identified) }\end{array}$ & $45390 \pm 10152$ & $159960 \pm 60116$ & + & $4 \pm 4$ \\
\hline${ }^{a}$ Undefined real chain length & & & & \\
\hline
\end{tabular}


Table 4. Species-specific response to light intensity and temperature changes (general regression model, best subsets, $\mathrm{R}^{2}$ ). See Table 3 for full species names. ${ }^{*} \mathrm{p}<0.05 ;{ }^{* *} \mathrm{p}<0.001$

\begin{tabular}{|c|c|c|c|c|c|c|c|}
\hline Species & Coefficient & SE & $t$ & $\mathrm{p}$ & df & $\mathrm{R}^{2}$ & $F$ \\
\hline \multicolumn{8}{|l|}{ C. pelagica } \\
\hline Light & 4.516 & 4.086 & 1.11 & 0.30 & \multirow[t]{2}{*}{2} & \multirow[t]{2}{*}{0.58} & \multirow[t]{2}{*}{$6.2^{*}$} \\
\hline Temperature & 1.792 & 0.534 & 3.36 & 0.01 & & & \\
\hline \multicolumn{8}{|l|}{ C. curvisetus } \\
\hline Light & -53.891 & 204.126 & -0.26 & 0.80 & \multirow[t]{2}{*}{2} & \multirow[t]{2}{*}{0.80} & \multirow[t]{2}{*}{$17.8^{* *}$} \\
\hline Temperature & 159.065 & 26.667 & 5.96 & $<0.001$ & & & \\
\hline \multicolumn{8}{|c|}{ Coscinodiscus sp. } \\
\hline Light & 0.141 & 0.056 & 2.53 & 0.03 & \multirow[t]{2}{*}{2} & \multirow[t]{2}{*}{0.87} & \multirow[t]{2}{*}{$30.2^{* *}$} \\
\hline Temperature & 0.053 & 0.007 & 7.35 & $<0.001$ & & & \\
\hline \multicolumn{8}{|l|}{ P. alata } \\
\hline Light & 17.078 & 7.711 & 2.21 & 0.05 & \multirow[t]{2}{*}{2} & \multirow[t]{2}{*}{0.84} & \multirow[t]{2}{*}{$30.2^{* *}$} \\
\hline Temperature & -1.672 & 1.007 & -1.66 & 0.13 & & & \\
\hline \multicolumn{8}{|c|}{ Pseudo-nitzschia sp. } \\
\hline Light & -6050.781 & 2812.708 & -2.15 & 0.06 & \multirow[t]{2}{*}{2} & 0.46 & 3.8 \\
\hline Temperature & -633.583 & 367.451 & -1.72 & 0.12 & & & \\
\hline R. setigera & & & & & & & \\
\hline Light & 19.844 & 19.356 & 1.03 & 0.33 & 2 & 0.84 & $30.2^{* *}$ \\
\hline Temperature & 10.127 & 2.529 & 4.00 & $<0.001$ & & & \\
\hline T. nitzschioides & & & & & & & \\
\hline Light & -159.219 & 235.983 & -0.67 & 0.52 & 2 & 0.11 & 0.6 \\
\hline Temperature & -25.017 & 30.829 & -0.81 & 0.44 & & & \\
\hline T. nordenskioel & & & & & & & \\
\hline Light & 24.219 & 104.391 & 0.23 & 0.82 & 2 & 0.27 & 1.7 \\
\hline Temperature & -24.667 & 13.638 & -1.81 & 0.10 & & & \\
\hline T. rotula & & & & & & & \\
\hline Light & 505.406 & 224.804 & 2.25 & 0.05 & 2 & 0.88 & $31.8^{* *}$ \\
\hline Temperature & 224.590 & 29.368 & 7.65 & $<0.001$ & & & \\
\hline C. minimum & & & & & & & \\
\hline Light & -273.438 & 2938.728 & -0.09 & 0.93 & 2 & 0.48 & 4.1 \\
\hline Temperature & 1105.333 & 383.914 & 2.88 & 0.02 & & & \\
\hline S. costatum & & & & & & & \\
\hline Light & 31088.281 & 18607.006 & 1.67 & 0.13 & 2 & 0.67 & $9.3^{*}$ \\
\hline Temperature & -9641.250 & 2430.809 & -3.97 & $<0.01$ & & & \\
\hline N. acicularis & & & & & & & \\
\hline Light & 17.813 & 30.271 & 0.59 & 0.57 & 2 & 0.04 & 0.2 \\
\hline Temperature & -0.850 & 3.955 & -0.21 & 0.83 & & & \\
\hline Rhodomonas sp & & & & & & & \\
\hline Light & -653.906 & 293.489 & -2.23 & 0.05 & 2 & 0.57 & $5.9^{*}$ \\
\hline Temperature & 99.867 & 38.341 & 2.60 & 0.03 & & & \\
\hline T. amphioxeia & & & & & & & \\
\hline Light & 487.766 & 227.660 & 2.14 & 0.06 & 2 & 0.78 & $15.7^{*}$ \\
\hline Temperature & 153.987 & 29.741 & 5.18 & $<0.01$ & & & \\
\hline C. tripos & & & & & & & \\
\hline Light & 0.078 & 0.035 & 2.22 & 0.05 & 2 & 0.48 & 4.1 \\
\hline Temperature & -0.008 & 0.005 & -1.81 & 0.10 & & & \\
\hline G. ostenfeldi & & & & & & & \\
\hline Light & 19.063 & 5.592 & 3.41 & 0.01 & 2 & 0.82 & $20.6^{* *}$ \\
\hline Temperature & 3.967 & 0.731 & 5.43 & $<0.001$ & & & \\
\hline H. rotundata & & & & & & & \\
\hline Light & 2791.250 & 1007.949 & 2.77 & 0.02 & 2 & 0.65 & $8.2^{*}$ \\
\hline Temperature & 388.900 & 131.678 & 2.95 & 0.02 & & & \\
\hline Picoplankton & & & & & & & \\
\hline Light & 72881.466 & 114894.982 & 0.63 & 0.54 & 2 & 0.35 & 2.5 \\
\hline Temperature & -31936.328 & 15009.818 & -2.13 & 0.06 & & & \\
\hline
\end{tabular}

separation of mesocosms according to the temperature regimes (462 permutations, global $R=1, \mathrm{p}=0.002$ ), while the different light regimes did not lead to separation (Fig. 5).

In order to test the potential impact of mesozooplankton grazing on the phytoplankton community, we compared species-specific abundance of copepods at the beginning and end of the experiment. ANOSIM based on the Bray-Curtis dissimilarity coefficient showed no separation at the beginning of the experiment (462 permutations, global $R=0.232, \mathrm{p}=$ 0.091; Fig. 6A) and clear separation according to temperature regime at the end of the experiment (462 permutations, global $R=1, \mathrm{p}=0.02$; Fig. 6B).

\section{DISCUSSION}

\section{Direct and indirect effects of temperature and light intensity on phytoplankton}

It has been frequently reported that warming should lead to an earlier phytoplankton spring bloom. In most cases, an earlier ice break or an earlier stabilization of the water column was connected with an earlier spring bloom (Edwards \& Richardson 2004, Elliott et al. 2006, Hashioka \& Yamanaka 2007). These findings suggest that the potentially accelerating factors of both temperature and light could be responsible for the earlier spring bloom.

Monitoring data from the coastal shallow waters of the western Baltic Sea have indicated a shift of the spring phytoplankton bloom of 1 to 2 wk earlier after warm winters (Göbel et al. 2009), which is in agreement with our findings. In contrast, Wiltshire \& Manly (2004) reported a retardation of the spring bloom by warming for the shallow German Bight of the North Sea. A later analysis with more years added to the time series found strong interannual variability but no trend related to warming (Wiltshire et al. 2008).

Other authors have suggested that temperature has little direct effect on algal growth, whereas light limitation 


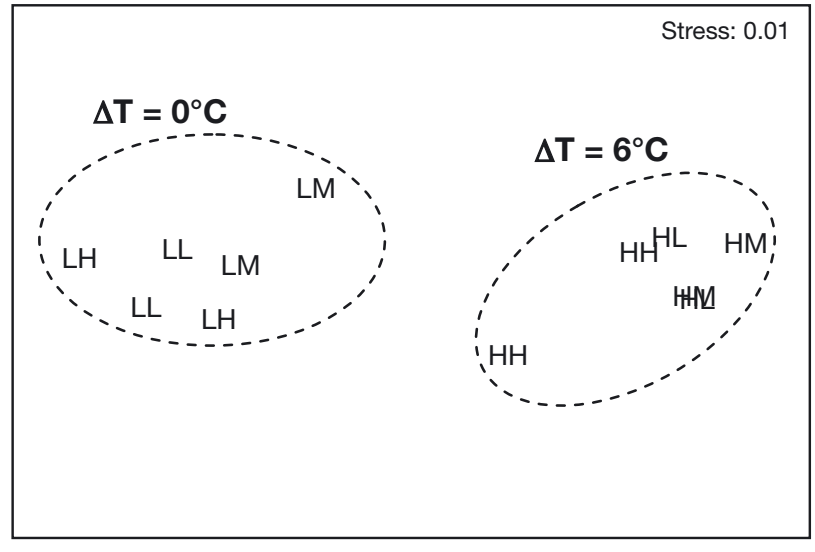

Fig. 5. Multidimensional scaling plot of variation in assemblages of phytoplankton among treatments. $\mathrm{HH}$ : high temperature and highest light intensity $\left(\Delta \mathrm{T}=6^{\circ} \mathrm{C}\right.$ and $64 \%$ of $\left.\mathrm{I}_{0}\right)$, $\mathrm{HM}$ : high temperature and middle light intensity $\left(\Delta \mathrm{T}=6^{\circ} \mathrm{C}\right.$ and $48 \%$ of $\left.\mathrm{I}_{0}\right)$; HL: high temperature and lowest light intensity $\left(\Delta \mathrm{T}=6^{\circ} \mathrm{C}\right.$ and $32 \%$ of $\left.\mathrm{I}_{0}\right) ; \mathrm{LH}$ : low temperature and highest light intensity $\left(\Delta \mathrm{T}=0^{\circ} \mathrm{C}\right.$ and $64 \%$ of $\left.\mathrm{I}_{0}\right) ; \mathrm{LM}$ : low temperature and middle light intensity $\left(\Delta \mathrm{T}=0^{\circ} \mathrm{C}\right.$ and $48 \%$ of $\left.\mathrm{I}_{0}\right) ; \mathrm{LL}$ : low temperature and the lowest light intensity $\left(\Delta \mathrm{T}=0^{\circ} \mathrm{C}\right.$ and $32 \%$ of $\mathrm{I}_{0}$ )

could be more important as the decisive factor for photosynthesis (Sommer et al. 1986, Moore et al. 1995, Sommer \& Lengfellner 2008). A previous study using the same mesocosm system and natural Baltic Sea plankton as inoculum suggests that light should have a stronger effect than the temperature on the timing of the spring bloom (Sommer \& Lengfellner 2008). However, this study did not utilize a factorial combination of the factors light and temperature. Sommer \& Lengfellner (2008) performed 3 experiments with 4 temperature levels each, but were able to test only one light level during each experiment. Given the usual interannual differences in natural plankton communities, this means that the factors light and inoculum (phytoplankton and zooplankton) were potentially confounded. Therefore, the parallel responses to temperature found between the different experiments were considered robust, but the conclusions related to light were only tentative.

In the present study, with a factorial combination of light and temperature within the same experiment, phytoplankton community responses to light limitation were related to temperature conditions. Light had a stronger impact on the timing of the phytoplankton maximum in the warmer mesocosms (Table 1). Surprisingly, however, we observed only a weak response of phytoplankton to the different light conditions in our experiment. Moreover, most of the phytoplankton species, especially bloom-forming Skeletonema costatum, Rhizosolenia setigera and Thalassiosira rotula, were rather insensitive to the different light treatments (Table 4). Admittedly, the range of the irradiance we tested was rather narrow ( 32 to $64 \%$ of $\mathrm{I}_{0}$ ), but a ratio of $>2: 1$ between the highest and the lowest light treatment is already quite broad, if we consider interannual differences at the time scale of bloom formation. However, on a day-to-day time scale, much bigger maximum to minimum ratios can be expected.

ANOSIM showed a very clear separation of phytoplankton community composition according to temperature, but no separation according to light (Fig. 5). We hypothesize that grazing could have had a stronger impact on phytoplankton community composition than light limitation. For mesozooplankton, we found little change in total abundance of copepods $(8 \pm 2$ [SD] ind. $\mathrm{l}^{-1}$ at the beginning of our experiment, $7 \pm 2[\mathrm{SD}]$ ind. $\mathrm{l}^{-1}$ at the end), but remarkable changes in species composition related to warming (Fig. 6). Typical overwintering species like Oithona sp. and Pseudocalanus sp. were replaced in warmer mesocosms by active grazers
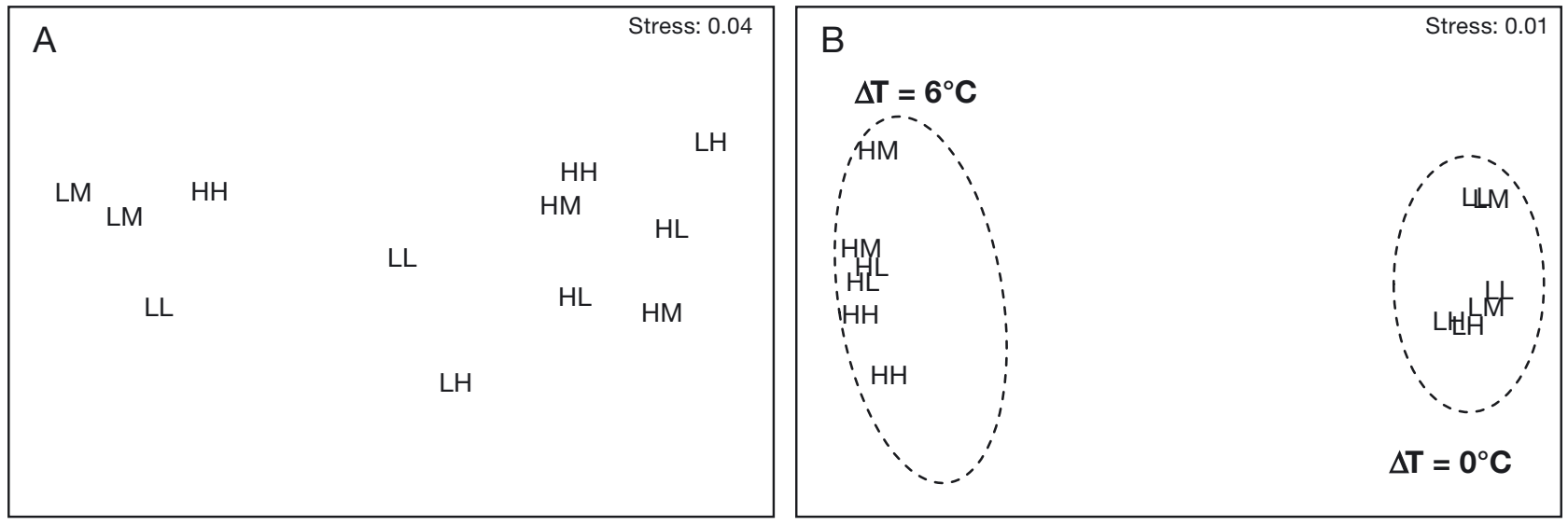

Fig. 6. Multidimensional scaling plots of variation in assemblages of zooplankton among treatments at (A) the beginning and (B) the end of the experiment. See Fig. 5 for temperature-light intensity abbreviations 
like Temora sp., Centropages sp. and Acartia sp. (data not shown), which are typically found later in the season in Kiel Bight (Behrends 1996). Because all prominent species in our experiment feed on the same phytoplankton size spectrum (>500 to $1000 \mu^{3}$ colony volume, Sommer \& Sommer 2006), potentially enhanced grazing rates with warming might lead to a reduction of the preferred phytoplankton species. A very strong temperature dependence of various activity parameters of Kiel Bight winter zooplankton has been shown by Isla et al. (2008).

Zooplankton food demand and grazing rates respond directly to temperature changes (Schalau et al. 2008). Both the lower total phytoplankton biomass and the shift towards smaller sizes at higher temperature can be interpreted as footprints of more intensive grazing by copepods and ciliates in the warmer mesocosms (Keller et al. 1999). Similarly, the more rapid decrease of biomass at the end of the bloom in warmer tanks could be also caused by a grazing effect (daily phytoplankton biomass decrease: $-0.32 \pm 0.07$ [SD] d ${ }^{-1}$ at $\Delta \mathrm{T}=0^{\circ} \mathrm{C}$ and $-0.42 \pm 0.01[\mathrm{SD}] \mathrm{d}^{-1}$ at $\Delta \mathrm{T}=6^{\circ} \mathrm{C}$ ). This decline was particularly apparent for diatoms, which are the preferred food for herbivorous mesozooplankton (Sommer et al. 1986, Granéli \& Turner 2002), but also for winter and early spring ciliates (Aberle et al. 2007). In contrast, there is a feeding preference for nanophytoplankton by summer ciliates (Sommer et al. 2005). We cannot rule out the feeding competition between ciliates and copepods in our experiment. However, higher abundance of picoplankton in warmer mesocosms might suggest that ciliates reduced the abundance of heterotrophic nanoflagellates and thus their feeding impact on picoplankton and bacteria.

Considering only the abiotic factors acting on phytoplankton, one would have hypothesized that the phytoplankton spring succession should be less dependent on temperature than light intensity, because of the relative insensitivity of light-limited production to temperature (Tilzer et al. 1986). However, the comprehensive analysis of phytoplankton species composition showed that the majority of the species present in the community was responsive to temperature changes. The effects of temperature on biomass, size structure and species composition are consistent with the assumption of an indirect temperature effect, acting via enhanced grazing. Enhanced zooplankton grazing at higher temperatures appeared to reverse the importance hierarchy of the factors light and temperature. While it is obvious that the stepwise and prominent light increase at the onset of stratification plays the dominant role in the initiation of the spring bloom in deep waters (Thackeray et al. 2008), the light differences used in our experiment did not play as big a role as was previously suspected (Sommer \& Lengfellner 2008).

\section{Changes in phytoplankton community structure and their implication for higher trophic levels}

The spring phytoplankton bloom in Kiel Bay, Baltic Sea, is usually dominated by diatoms, in many years exemplified by a high abundance of Skeletonema costatum (Tilstone et al. 2000). The same community composition was observed in our experiment, where S. costatum was the most abundant species in all treatments and played a major role in forming the phytoplankton bloom in all mesocosms (Table 3). In an analysis of a long-term data set of the phytoplankton community in Kiel Bight, Wasmund et al. (2008) presented changes in phytoplankton biomass and species composition similar to those we observed in our mesocosm experiment. Thus, the community structure in the present study was typical and representative of the spring phytoplankton bloom in this region of the Baltic Sea.

Diatom blooms are usually composed of a few co-dominant species (Smayda \& Reynolds 2003), as was found in the present study. We found conspicuous, temperaturerelated changes in phytoplankton composition affecting both rare and dominant species like Thalassiosira rotula and Chaetoceros curvisetus (Table 3). The abundance of these species was strongly reduced in the warmer mesocosms, and there was a concomitant decrease in the number of co-dominant species forming the bloom.

Some authors hypothesize a shift to smaller species with an increase in temperature (Hashioka \& Yamanaka 2007). In the present study, we also observed higher biomass of picophytoplankton (Table 3) and smaller mean cell sizes in warmer conditions (Table 2). As mentioned above, the shift to smaller cell sizes with warming might be caused by enhanced grazing on larger phytoplankton species. On the other hand, physiological and metabolic changes related to warming are also possible and might change the outcome of coexistence and competition between different phytoplankton species (Brown et al. 2004).

The observed changes in phytoplankton species composition and the shift to smaller cell sizes with warming could have important consequences for the pelagic food web. Phytoplankton species that are impacted negatively by climate change are reduced, thus permitting increases for other, better adapted organisms. The result of such species shifts is a change in the quality of food available for higher trophic levels, as picophytoplankton and small nanophytoplankton $\left(<500 \mathrm{\mu m}^{3}\right.$ cell volume) species are inedible for copepods (Sommer \& Sommer 2006). In such a case, the path of carbon flow between primary producers and mesozooplankton may become longer through heterotrophic flagellates and ciliates, which can reduce productivity of higher trophic levels, as described by Berglund et al. (2007). 
The changes in phytoplankton community structure were mostly caused by temperature. Results of the present study indicate that indirect temperature effects, e.g. enhanced grazing pressure with warming, might strongly modify the size range and composition of the phytoplankton community. Understanding the interactions between direct and indirect effects of warming and the relationships between different species might be essential to predict the consequences of climate change.

Acknowledgements. This project was funded by the priority program 1162 AQUASHIFT of the German Research Foundation (DFG). The authors thank T. Hansen and H. Tomanetz for technical support. C. Meyer and S. Büddicker are acknowledged for help with sampling and A. Biermann for nutrient data. A.L. thanks K. Lengfellner and P. Breithaupt for an introduction to the practical work. J. Testa is thanked for comments and improving the language.

\section{LITERATURE CITED}

Aberle N, Lengfellner K, Sommer U (2007) Spring bloom succession, grazing impact and herbivore selectivity of ciliate communities in response to winter warming. Oecologia 150:668-681

Behrends G (1996) Long-term investigation of seasonal zooplankton dynamics in Kiel Bight, Germany. Proceedings of the 13th Baltic Marine Biology Symposium, Jurmala, Institute of Aquatic Ecology, University of Latvia, Riga, p 93-98

Berger SA, Diehl S, Stibor H, Trommer G and others (2007) Water temperature and mixing depth affect timing and magnitude of events during spring succession of the plankton. Oecologia 150:643-654

Berglund J, Müren U, Bamstedt U, Andersson A (2007) Efficiency of a phytoplankton-based and bacteria-based food web in pelagic marine system. Limnol Oceanogr 52:121-131

Brock TD (1981) Calculating solar radiation for ecological studies. Ecol Model 14:1-19

Brown JH, Gillooly JF, Allen AP, Savage VM, West GB (2004) Toward a metabolic theory of ecology. Ecology 85: 1771-1789

Cushing DH (1990) Plankton production and year-class strength in fish populations: an update of the match/mismatch hypothesis. Adv Mar Biol 26:249-293

Durant JM, Hjermann DO, Anker-Nilssen T, Beaugrand G, Mysterud A, Pettorelli N, Stenseth NC (2005) Timing and abundance as key mechanisms affecting trophic interactions in variable environments. Ecol Lett 8:952-958

Edwards M, Richardson AJ (2004) Impact of climate change on marine pelagic phenology and trophic mismatch. Nature 430:881-884

Elliott JA, Jones ID, Thackeray SJ (2006) Testing the sensitivity of phytoplankton communities to changes in water temperature and nutrient load, in a temperate lake. Hydrobiologia 559:401-411

Gargas E (1975) A manual for phytoplankton primary production studies in the Baltic. BMB Publishing, Horsholm

Göbel J, Lu D, Voß J (2009) Potential impact of climate change on marine phytoplankton with emphasis on the German coastal waters and the East China Sea. Jahresber Landesamtes Natur Umwelt Landes Schleswig-Holstein 2007: $75-82$
Granéli E, Turner JT (2002) Top-down regulation in ctenophore-copepod-ciliate-diatom-phytoflagellate communities in coastal waters: a mesocosm study. Mar Ecol Prog Ser 239:57-68

Hashioka T, Yamanaka Y (2007) Ecosystem change in the western North Pacific associated with global warming using 3D-NEMURO. Ecol Model 202:95-104

Hillebrand H, Dürselen CD, Kirschtel D, Pollingher U, Zohary $\mathrm{T}$ (1999) Biovolume calculation for pelagic and benthic microalgae. J Phycol 35:403-424

- Huisman J, Sharples J, Stroom JM, Visser PM, Kardinaal WEA, Verspagen JMH, Sommeijer B (2004) Changes in turbulent mixing shift competition for light between phytoplankton species. Ecology 85:2960-2970

IPCC (Intergovernmental Panel on Climate Change) (2007) Climate change 2007: the physical science basis. In: Solomon S, Qin D, Manning M, Chen Z and others (eds) Contribution of Working Group I to the fourth assessment report of the Intergovernmental Panel on Climate Change. Cambridge University Press, Cambridge

Isla JA, Lengfellner K, Sommer U (2008) Physiological response of the copepod Pseudocalanus sp in the Baltic Sea at different thermal scenarios. Global Change Biol 14: 895-906

Keller AA, Oviatt CA, Walker HA, Hawk JD (1999) Predicted impacts of elevated temperature on the magnitude of the winter-spring phytoplankton bloom in temperate coastal waters: a mesocosm study. Limnol Oceanogr 44:344-356

Menden-Deuer S, Lessard EJ (2000) Carbon to volume relationships for dinoflagellates, diatoms, and other protist plankton. Limnol Oceanogr 45:569-579

> Moore LR, Goericke R, Chisholm SW (1995) Comparative physiology of Synechococcus and Prochlorococcus: influence of light and temperature on growth, pigments, fluorescence and absorptive properties. Mar Ecol Prog Ser 116:259-275

> Mueter FJ, Broms C, Drinkwater KF, Friedland KD and others (2009) Ecosystem responses to recent oceanographic variability in high-latitude Northern Hemisphere ecosystems. Prog Oceanogr 81:93-110

> Nixon SW, Fulweiler RW, Buckley BA, Granger SL, Nowicki BL, Henry KM (2009) The impact of changing climate on phenology, productivity, and benthic-pelagic coupling in Narragansett Bay. Estuar Coast Shelf Sci 82:1-18

Reynolds C (2006) Ecology of phytoplankton. Cambridge University Press, New York

Rose JM, Feng YY, Gobler CJ, Gutierrez R, Hare CE, Leblanc $\mathrm{K}$, Hutchins DA (2009) Effects of increased $\mathrm{pCO}_{2}$ and temperature on the North Atlantic spring bloom. II. Microzooplankton abundance and grazing. Mar Ecol Prog Ser 388:27-40

> Schalau K, Rinke K, Straile D, Peeters F (2008) Temperature is the key factor explaining interannual variability of Daphnia development in spring: a modelling study. Oecologia 157:531-543

Schiermeier Q (2006) A sea change. Nature 439:256-260

Smayda TJ, Reynolds CS (2003) Strategies of marine dinoflagellate survival and some rules of assembly. J Sea Res 49:95-106

Smetacek V, Cloern JE (2008) On phytoplankton trends. Science 319:1346-1348

> Sommer U, Lengfellner K (2008) Climate change and the timing, magnitude, and composition of the phytoplankton spring bloom. Global Change Biol 14:1199-1208

Sommer U, Sommer F (2006) Cladocerans versus copepods: the cause of contrasting top-down controls on freshwater and marine phytoplankton. Oecologia 147:183-194 
Sommer U, Gliwicz ZM, Lampert W, Duncan A (1986) The PEG model of seasonal succession of planktonic events in freshwaters. Hydrobiologia 106:433-471

Sommer U, Hansen T, Blum O, Holzner N, Vadstein O, Stibor $\mathrm{H}$ (2005) Copepod and microzooplankton grazing in mesocosms fertilised with different Si:N ratios: no overlap between food spectra and Si:N influence on zooplankton trophic level. Oecologia 142:274-283

Sommer U, Aberle N, Engel A, Hansen T and others (2007) An indoor mesocosm system to study the effect of climate change on the late winter and spring succession of Baltic Sea phyto- and zooplankton. Oecologia 150:655-667

Sverdrup HU (1953) On conditions for the vernal blooming of phytoplankton. J Cons Int Explor Mer 18:287-295

Thackeray SJ, Jones ID, Maberly SC (2008) Long-term change in the phenology of spring phytoplankton: species-specific responses to nutrient enrichment and climatic change. J Ecol 96:523-535

Tilstone GH, Miguez BM, Figueiras FG, Fermin EG (2000) Diatom dynamics in a coastal ecosystem affected by upwelling: coupling between species succession, circulation and biogeochemical processes. Mar Ecol Prog Ser 205:23-41

Editorial responsibility: Hans Heinrich Janssen, Oldendorf/Luhe, Germany
Tilzer MM， Elbrächter M, Gieskes W, Beese B (1986) Light-temperature interactions in the control of photosynthesis in Antarctic phytoplankton. Polar Biol 5:105-111

Townsend DW, Cammen LM, Holligan PM, Campbell DE, Pettigrew NR (1994) Causes and consequences of variability in the timing of spring phytoplankton blooms. DeepSea Res I 41:747-765

Utermöhl H (1958) Zur Vervollkommung der quantitativen Phytoplankton Methodik. Mitt Int Ver Theor Angew Limnol 9:263-272

> Wasmund N, Gobel J, Von Bodungen B (2008) 100-yearschanges in the phytoplankton community of Kiel Bight (Baltic Sea). J Mar Syst 73:300-322

- Wiltshire KH, Manly BFJ (2004) The warming trend at Helgoland Roads, North Sea: phytoplankton response. Helgol Mar Res 58:269-273

Wiltshire KH, Malzahn AM, Wirtz K, Greve W and others (2008) Resilience of North Sea phytoplankton spring bloom dynamics: an analysis of long-term data at Helgoland Roads. Limnol Oceanogr 53:1294-1302

Winder M, Schindler DE (2004) Climate change uncouples trophic interactions in an aquatic ecosystem. Ecology 85: $2100-2106$

Submitted: July 22, 2009; Accepted: February 1, 2010 Proofs received from author(s): April 23, 2010 